\title{
Patterns of phytoplankton size structure and productivity in contrasting open-ocean environments
}

\author{
Emilio Marañón ${ }^{1, *}$, Patrick M. Holligan² ${ }^{2}$ Rosa Barciela ${ }^{3}$, Natalia González ${ }^{4}$, \\ Beatriz Mouriño ${ }^{1}$, María J. Pazó ${ }^{1}$, Manuel Varela ${ }^{5}$ \\ ${ }^{1}$ Departamento de Ecoloxía e Bioloxía Animal, Facultade de Ciencias, Universidade de Vigo, 36200 Vigo, Spain \\ ${ }^{2}$ School of Ocean and Earth Science, University of Southampton and ${ }^{3}$ James Rennell Division for Ocean Circulation and Climate, \\ Southampton Oceanography Centre, Southampton SO14 3ZH, United Kingdom \\ ${ }^{4}$ Departamento de Biología de Organismos y Sistemas, Facultad de Biología, Universidad de Oviedo, 33006 Oviedo, Spain \\ ${ }^{5}$ Instituto Español de Oceanografía, Centro Oceanográfico de A Coruña, Apdo 130, 15080 A Coruña, Spain
}

\begin{abstract}
A total of 94 vertical profiles of size-fractionated chlorophyll a concentration and primary production rate were obtained along a meridional transect from the United Kingdom to the Falkland Islands $\left(50^{\circ} \mathrm{N}\right.$ to $\left.50^{\circ} \mathrm{S}\right)$ during 4 cruises carried out in April and October 1996 and in April and October 1997. This data set allowed us to characterize the patterns of phytoplankton size-structure and productivity in temperate, oligotrophic, upwelling and equatorial regions. On average, picophytoplankton $(0.2$ to $2 \mu \mathrm{m})$ accounted for 56 and $71 \%$ of the total integrated carbon (C) fixation and autotrophic biomass, respectively. Enhanced biomass and productivity contributions by nano- and microplankton took place in the temperate regions and in the upwelling area off Mauritania. Small $(<2 \mu \mathrm{m}$ in diameter) phytoplankton cells should not be regarded as a background, relatively invariant component of the microbial community, given that most of the latitudinal variability in total photoautotrophic biomass and production was driven by changes in the picophytoplankton. In temperate regions and in the upwelling area off Mauritania, small $(<2 \mu \mathrm{m})$ and large $(>2 \mu \mathrm{m})$ phytoplankton accounted for a proportion of total biomass that was similar to their shares of productivity. In the oligotrophic and equatorial regions, in contrast, large phytoplankton tended to account for a fraction of the total production that was significantly higher than their share of the biomass. We found that the equatorial upwelling causes an increase in phytoplankton biomass and productivity without altering the typical size structure found in less productive regions such as the subtropical gyres. In the oligotrophic ocean, significant changes in $\mathrm{C}$ fixation rates take place without accompanying variations in the magnitude of the phytoplankton standing stocks or the size structure of the microbial community.
\end{abstract}

KEY WORDS: Size distribution · Phytoplankton $\cdot$ Chlorophyll $\cdot$ Primary production $\cdot$ Plankton food webs $\cdot$ Atlantic Ocean

Resale or republication not permitted without written consent of the publisher

\section{INTRODUCTION}

The size distribution of phytoplankton assemblages is a major biological factor that governs the functioning of pelagic food-webs and consequently affects the rate of carbon (C) export from the upper ocean to deep layers (Malone 1980, Legendre \& Le Fèvre 1991).

\footnotetext{
*E-mail: em@uvigo.es
}

(c) Inter-Research 2001
Depending on the different combinations of production and biomass of small and large phytoplankton, the dominant $\mathrm{C}$ pathways may be represented by in situ recycling, transfer to upper trophic levels, or sedimentation to the deep ocean. It has been shown that different ecological domains in the ocean can be characterized, in terms of potential export of biogenic $\mathrm{C}$, according to the relative contribution of large phytoplankton to total biomass and production (Tremblay \& Legendre 1994). Ultimately, the food-web properties 
which determine the magnitude of different $\mathrm{C}$ pathways (i.e. size structure of primary production and coupling between production and grazing) are, in turn, under hydrodynamical control (Legendre \& Rassoulzadegan 1996).

Numerous studies have been carried out in which size-fractionated chlorophyll concentration and primary production are simultaneously quantified in particular geographical areas (see reviews in Tremblay \& Legendre 1994, Legendre \& Rassoulzadegan 1996). The majority of these observations, however, have been made in coastal and/or temperate environments, with relatively little attention given to tropical and subtropical open-ocean environments. In the tropical and subtropical Atlantic Ocean, only a few studies have dealt with the distribution of size-fractionated phytoplankton (i.e. Platt et al. 1983, Malone et al. 1993, Jochem \& Zeitzschel 1993), and these have not considered temporal and spatial variability simultaneously. Furthermore, virtually no information is available on the variability of phytoplankton in the South Atlantic subtropical gyre, as evidenced in the global distribution of chlorophyll profiles used by Longhurst et al. (1995) to construct their model of global ocean productivity. All these shortcomings limit the general applicability of pelagic ecosystem models, which increasingly rely on the use of size-fractionated plankton data (Armstrong 1994, Fasham et al. 1999). Clearly more information is needed on the large-scale distribution and temporal variability of size-fractionated phytoplankton biomass and production if we are to improve our understanding of the functioning of marine ecosystems.

A widely accepted paradigm in marine phytoplankton ecology is that most of the temporal and geographical variability in total biomass and productivity is associated with changes in the large size fractions, the picoplankton being regarded as a 'background' component whose abundance and activity remain fairly constant (Raimbault et al. 1988, Chisholm 1992, Rodríguez et al. 1998). If the increases in productivity are due to an enhanced contribution by larger cells, changes in total primary production should always be associated with modifications in size distribution and food-web structure. While this process has been demonstrated for temperate (Furnas 1983, Joint et al. 1992) and high-latitude (Bienfang 1984, Jochem 1989) regions, it has yet to be confirmed for the lowproductivity waters of the open ocean.

The central gyres of the open ocean have traditionally been regarded as near-constant environments where temporal changes in primary production rates are low. Modern time series, however, have shown a large degree of variability in phytoplankton production rates (Malone et al. 1993, Karl et al. 1996). Recent studies on the large-scale variability of the Atlantic Ocean report temporal changes of a factor of $>5$ in the photophysiology (Marañón \& Holligan 1999) and growth rates (Marañón et al. 2000) of phytoplankton in the subtropical gyres. It is still unresolved, nonetheless, to which extent these changes in phytoplankton growth and productivity are accompanied by modifications in size structure, which could affect the potential C export towards the deep ocean. This question needs to be addressed in the light of recent estimates which suggest that open-ocean regions may account for $70 \%$ of the total export production in the ocean (Karl et al. 1996).

In this paper, we describe the latitudinal distribution of size-fractionated phytoplankton chlorophyll $a(\mathrm{chl} a)$ and production in the Atlantic Ocean from $50^{\circ} \mathrm{N}$ to $50^{\circ} \mathrm{S}$. We present results from 4 cruises conducted during 1996 and 1997, which allow us to quantify the temporal variability in the large-scale distribution of phytoplankton dynamics. Our study of size-fractionated phytoplankton is unprecedented in that it covers a wide range of temperate, subtropical, equatorial and upwelling regions, using consistent methodology and including a component of temporal variability over a $2 \mathrm{yr}$ period. These observations are used to further characterize different oceanic regions according to the distribution of biomass and production in small and large phytoplankton. Finally, we focus on the temporal variability in the productivity of the oligotrophic gyres in order to assess whether or not the observed changes are associated with shifts in the food-web structure of the planktonic ecosystem.

\section{METHODS}

Sampling was conducted during 4 cruises on board RRS 'James Clark Ross' on passage between Great Britain $\left(\sim 50^{\circ} \mathrm{N}\right)$ and the Falkland Islands $\left(\sim 50^{\circ} \mathrm{S}\right)$ as part of the Atlantic Meridional Transect (AMT) research programme (Fig. 1). The sampling periods were 22 April to 22 May 1996 (AMT-2), 16 September to 25 October 1996 (AMT-3), 22 April to 20 May 1997 (AMT-4) and 18 September to 15 October 1997 (AMT5). Full descriptions of the sampling strategy and the acquisition of complementary physical and chemical variables are available in Marañón \& Holligan (1999) and Marañón et al. (2000). Here, we describe in detail the methodology used for the determination of the vertical distribution of size-fractionated chl a concentration and the rate of primary production.

Vertical profiles of size-fractionated chl a concentration and primary production were obtained at intervals of approximately 270 nautical miles between $50^{\circ} \mathrm{N}$ and $50^{\circ} \mathrm{S}$. At each station, water samples from 7 depths in the upper $200 \mathrm{~m}$ of the water column were collected using metal-clean techniques. Sampling depths were 
chosen after examining the irradiance, temperature, salinity and fluorescence profiles. Sampling was conducted between 10:00 and 11:00 h local time. Chl a concentration was determined fluorometrically on $250 \mathrm{ml}$ samples which were sequentially filtered through 20 , 2 and $0.2 \mu \mathrm{m}$ pore size polycarbonate filters. Cells retained by the $20 \mu \mathrm{m}$ filters belong to the microplankton, whereas those retained by the 2 and $0.2 \mu \mathrm{m}$ pore-size filters constitute, respectively, the nanoplankton and the picoplankton (Sieburth et al. 1978). After filtration, pigment extraction was carried out by storing the filters in $90 \%$ acetone at $-20^{\circ} \mathrm{C}$ overnight. Samples were then analysed using a 10 AU Turner Designs Fluorometer, which was calibrated before and after each cruise using pure chl a as a standard.

We carried out simulated in situ incubations with the radioisotope ${ }^{14} \mathrm{C}$ in order to determine the rates of carbon fixation by each size class of phytoplankton. Samples for the productivity experiments were drawn from the same water bottles used for pigment analysis. Immediately after collection, seawater samples from each sampling depth were transferred to $70 \mathrm{ml}$ acid-cleaned polycarbonate bottles, inoculated with 370 to $555 \mathrm{kBq}$ (10 to $15 \mu \mathrm{Ci}$ ) $\mathrm{NaH}^{14} \mathrm{CO}_{3}$ and incubated for 6 to $7 \mathrm{~h}$ until sunset. For each depth, 3 light bottles and 1 dark bottle were incubated. Samples were placed inside acrylic neutral-density tubes which were refrigerated by a system of running seawater pumped from the sea surface. Irradiance profiles were simulated, according to the vertical PAR distribution determined before the start of the experiment, by using a set of neutral-density and blue plastic filters. At the end of the incubations, samples were sequentially filtered through 20,2 and $0.2 \mu \mathrm{m}$ polycarbonate filters under low-vacuum pressure ( $<100 \mathrm{~mm} \mathrm{Hg}$ ). Decontamination of the filters was achieved by exposing them to concentrated $\mathrm{HCl}$ fumes for $12 \mathrm{~h}$. After decontamination, the filters were transferred to scintillation vials to which $4 \mathrm{ml}$ of scintillation cocktail were added. Radioactivity on each sample was measured on a Beckman LS6000 SC scintillation counter, using the channel ratio method to correct for quenching. For calculation of the rates of carbon incorporation, dpm values from the dark bottles were subtracted from the counts measured in the light samples. The standard error of the productivity estimates typically represented less than $10 \%$ of the average. Hourly rates were calculated by dividing the $\mathrm{C}$ incorporation during the experiment by the duration of the incubation. Daily production rates were calculated by (1) taking into account the incident irradiance integrated over both the incubation and the daylight period and (2) assuming that dark respiratory losses amount to $20 \%$ of the C incorporation during the light period (Geider 1992).

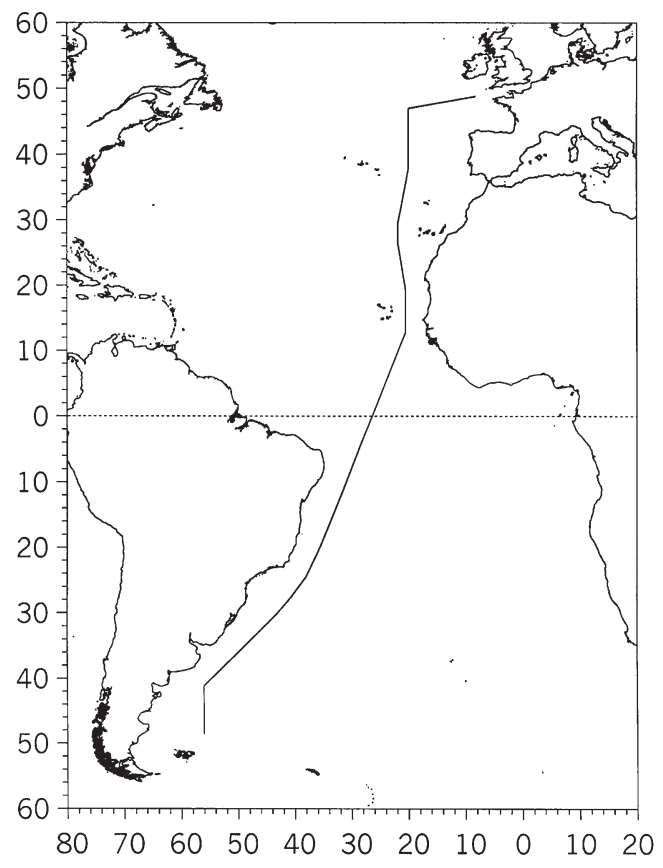

Fig. 1. Cruise track along the Atlantic Meridional Transect (AMT)

\section{RESULTS}

The general patterns of vertical and latitudinal distribution of total phytoplankton biomass, composition and production during the AMT cruises, as well as the distribution of dissolved nutrients and the physical structure of the water column have already been described by Marañón et al. (2000). We therefore concentrate here on the patterns of distribution of chl a and production in each particular size class, with an emphasis on temporal variability.

\section{Size-fractionated chlorophyll a}

The latitudinal distribution of the picoplankton $(0.2$ to $2 \mu \mathrm{m}) \mathrm{chl}$ a (Fig. 2) closely reflected the patterns of abundance of total phytoplankton, given that this fraction accounted for more than $60 \%$ of total chl a during most of the transect. Highest levels of phytoplankton chl a were observed in temperate waters at both ends of the transect and also between the equator and $20^{\circ} \mathrm{N}$ as the transect crossed the coastal upwelling region off Mauritania (see Fig. 4 of Marañón et al. 2000). The oligotrophic gyres showed the lowest abundances of phytoplankton biomass, with picoplankton chl a values below $0.1 \mathrm{mg} \mathrm{m}^{-3}$ throughout the upper mixed layer. Flow cytometry analyses (Zubkov et al. 1998) indicated that the cyanobacterium Prochlorococcus spp. and 

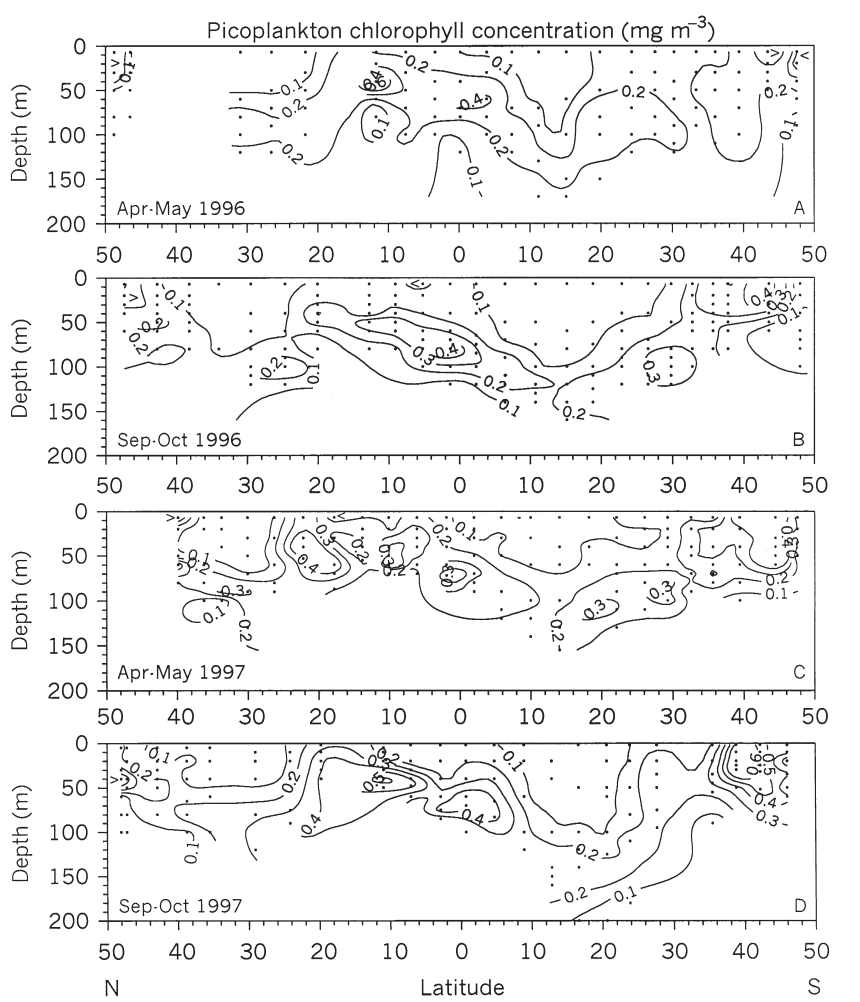

Fig. 2. Latitudinal distribution of ch a concentration in picoplankton $(0.2$ to $2 \mu \mathrm{m})$ size fraction
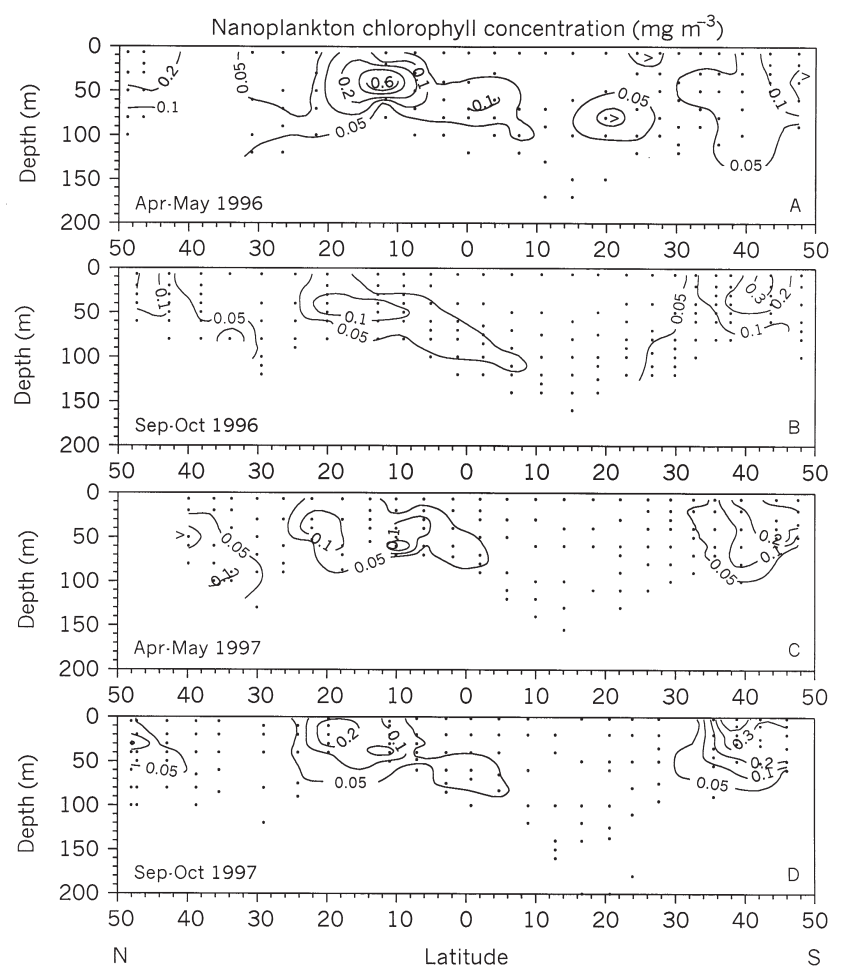

Fig. 3. Latitudinal distribution of chl $a$ in nanoplankton (2 to $20 \mu \mathrm{m})$ size fraction picoeukaryotic algae constituted the bulk of the picoplanktonic carbon biomass during most of the transect.

The most conspicuous feature regarding the vertical pigment distribution was the presence of a deep chl a maximum (DCM) located at the base of the upper mixed layer in tropical and subtropical regions. The location of the DCM changed with latitude according to variations in the structure of the water column. Consequently, the DCM was deeper in the South Atlantic oligotrophic gyre than in the North Atlantic oligotrophic gyre, and it was significantly shallower between the equator and $20^{\circ} \mathrm{N}$, reflecting the influence of the Mauritanian upwelling. Picoplankton chl a concentration at the DCM was generally between 0.2 and $0.3 \mathrm{mg} \mathrm{m}^{-3}$, reaching values above $0.4 \mathrm{mg} \mathrm{m}^{-3}$ in regions affected by the equatorial or the Mauritanian upwelling (Fig. 2). Both in the upwelling and the temperate regions, where total phytoplankton concentration was higher (Marañón et al. 2000), the contribution of picoplankton to total chl a was lower.

Nanoplankton (2 to $20 \mu \mathrm{m}$ ) chl a concentration was markedly lower than that of picoplankton, typical values at the DCM being in the range of 0.05 to 0.2 (Fig. 3). Highest values (>0.2 to $0.3 \mathrm{mg} \mathrm{m}^{-3}$ ) were generally recorded in surface and subsurface waters at temperate latitudes, particularly in the South Atlantic. Throughout the euphotic layer in tropical and subtropical waters and in the upper mixed layer in the equatorial region, the concentration of nanoplankton chl a was below $0.05 \mathrm{mg} \mathrm{m}^{-3}$.

Microplankton (>20 $\mu \mathrm{m})$ was present in concentrations above $0.2 \mathrm{mg} \mathrm{m}^{-3}$ only in the upwelling region off Mauritania and in the temperate regions (Fig. 4). In the rest of the transect, the concentration of chl a in this size fraction was permanently below $0.05 \mathrm{mg}$ $\mathrm{m}^{-3}$. Highest concentrations of microplankton chl a were recorded in the North Atlantic during May 1996, coinciding with the late stages of the spring bloom, when $>60 \%$ of the chl a belonged to the largest size fraction. Excluding high-productivity waters in temperate regions, the contribution of microplankton to total chl a was generally very low. The similar distributions of diatom abundance (Marañón et al. 2000) and the relative contribution of nanoand microplankton to total chl a strongly suggest that these size fractions mainly comprised diatoms, with dinoflagellates and coccolithophorids being comparatively less important.

Fig. 5 shows the latitudinal variability in total and size-fractionated chl a integrated over the euphotic zone. Typical values of integrated total chl $a$ in the oligotrophic regions were in the range 20 to $30 \mathrm{mg} \mathrm{m}^{-2}$, and they experienced little change between cruises. Higher chl a concentrations were found near the equa- 


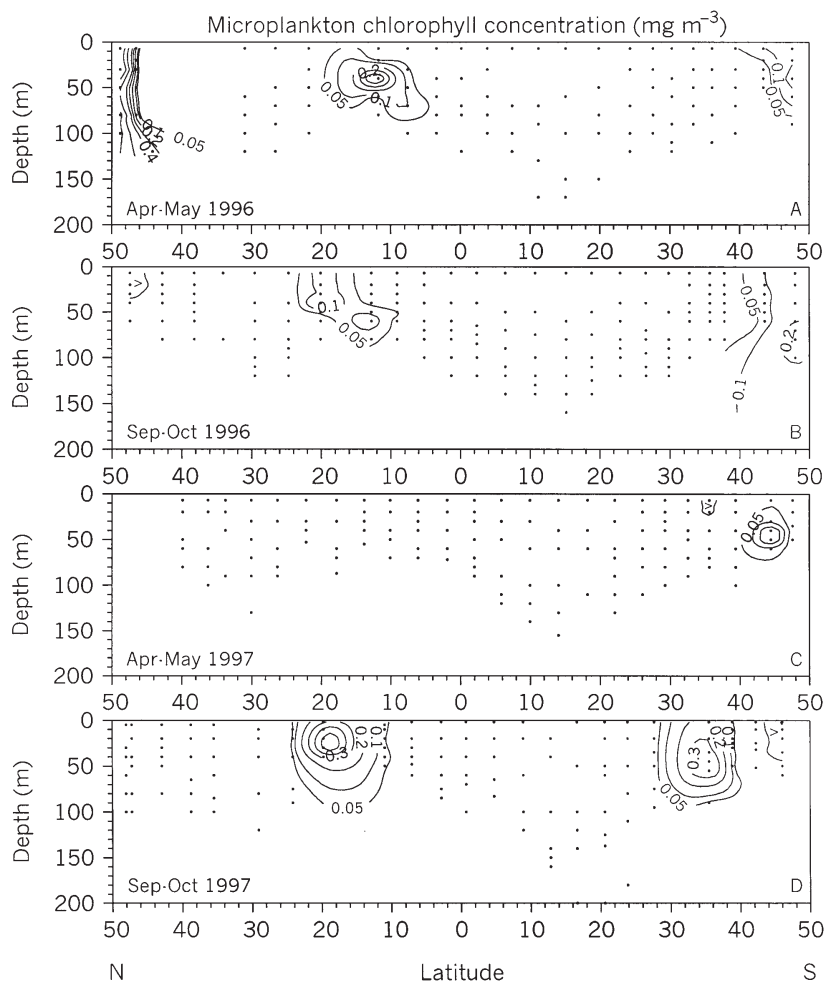

Fig. 4. Latitudinal distribution of $\mathrm{chl}$ a in microplankton $(>20 \mu \mathrm{m})$ size fraction

tor and in the upwelling region off Mauritania, where integrated values reached 40 to $60 \mathrm{mg} \mathrm{m}^{-2}$ in April and May 1996 and September and October 1997 (Fig. 4A,D). In general, integrated chl a increased noticeably towards both ends of the transect, as temperate waters with enhanced vertical mixing were sampled.

The elevations in chl a concentration were paralleled by an increased contribution of nanoplankton and microplankton to total $\mathrm{chl} a$, although picoplankton constituted the dominant size fraction during most of the study, accounting for 60 to $80 \%$ of total integrated chl a (Fig. 5). Nanoplankton typically represented $\sim 20 \%$ of total $\mathrm{chl}$ a in low-productivity regions, increasing up to $>30 \%$ in temperate regions. The percentage of chl a accounted for by microplankton was very small $(<10 \%)$ during most of the transect, increasing above $20 \%$ at the upwelling region near $20^{\circ} \mathrm{N}$ (Fig. 5B,D) and also in temperate waters, especially during spring (Fig. 5A,B). Using stepwise regression analysis, we tried to quantify the amount of variability in total integrated chl a concentration that was explained by the changes in chl a concentration in each size fraction. We excluded from the analysis all the stations where total chl a concentration was above $40 \mathrm{mg}$ $\mathrm{m}^{-2}$ (less than $10 \%$ of the total number of observations). Total chl a concentration was taken as a dependent variable and pico-, nano- and microplankton chl $a$ were the independent variables. Picoplankton, nanoplankton and microplankton explained, respectively, 61,29 and $9 \%$ of the variability in total chl a concentration.

\section{Size-fractionated primary production}

The general picture of primary productivity along the transect reflects closely the patterns of latitudinal distribution of pigment concentration that have just been described. In accordance with their large share of chl a concentration, picoplankton were the most productive size fraction during most of the study (Fig. 6). Highest rates of productivity by picoplankton ( $>1 \mathrm{mgC}$ $\mathrm{m}^{-3} \mathrm{~h}^{-1}$ ) were measured in surface waters of the South Atlantic $\left(\sim 40^{\circ} \mathrm{S}\right)$. Typical values of picoplankton production in surface and subsurface waters of temperate and upwelling regions were 0.4 to $0.8 \mathrm{mgC} \mathrm{m}^{-3} \mathrm{~h}^{-1}$. In the oligotrophic gyres, production rates below 0.05 to

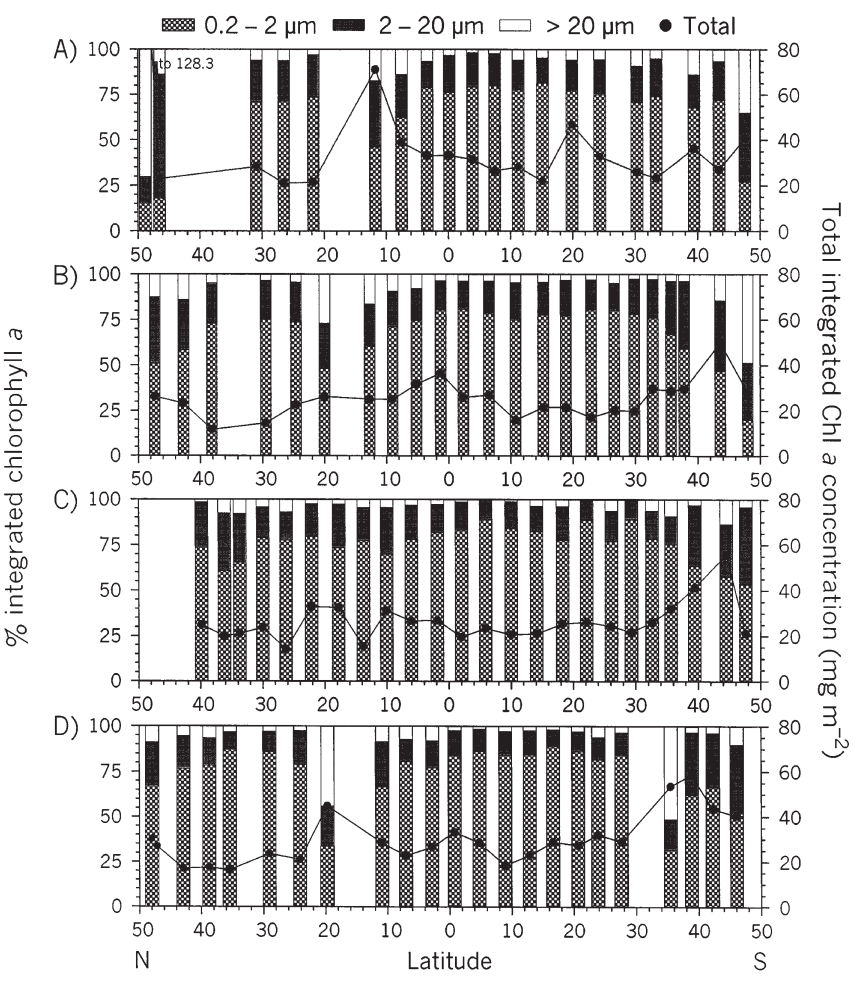

Fig. 5. Total, euphotic layer-integrated chl a concentration $\left(\bullet, \mathrm{mg} \mathrm{m}^{-2}\right)$ and the relative contribution (\%) of picoplankton (0.2 to $2 \mu \mathrm{m})$, nanoplankton (2 to $20 \mu \mathrm{m}$ ) and microplankton $(>20 \mu \mathrm{m})$ to total integrated chl a during (A) April and May 1996, (B) September and October 1996, (C) April and May 1997 and (D) September and October 1997 


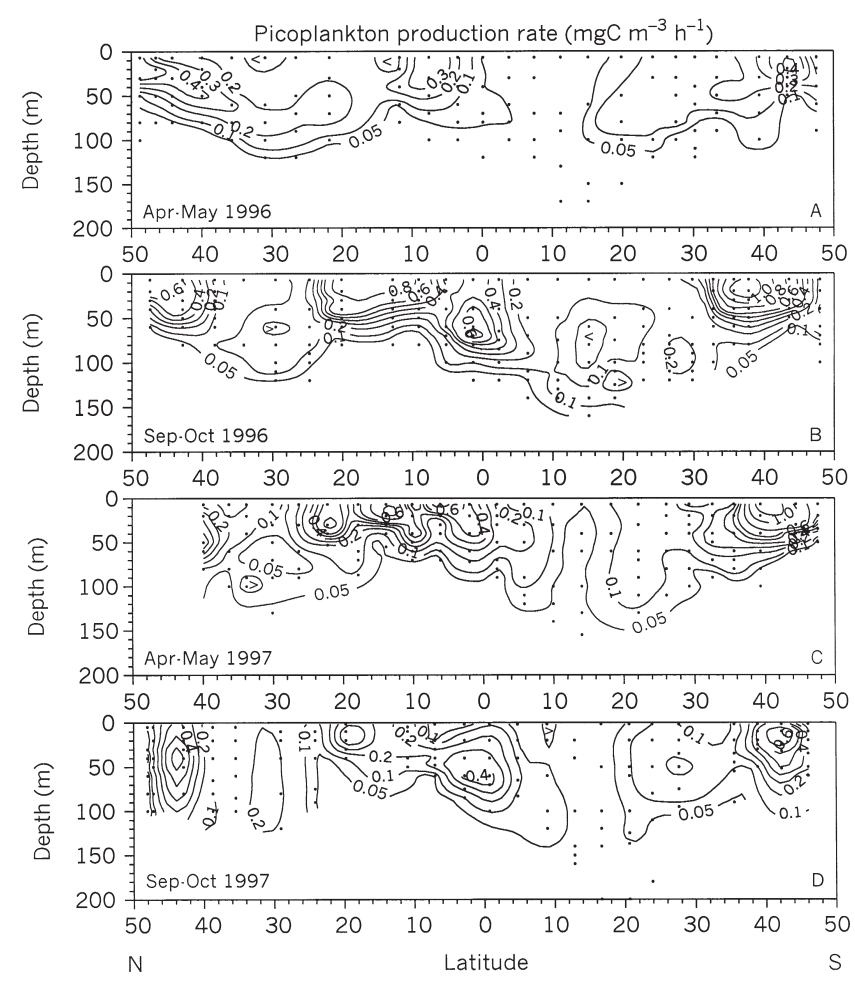

Fig. 6. Latitudinal distribution of primary production in picoplankton $(0.2$ to $2 \mu \mathrm{m})$ size fraction

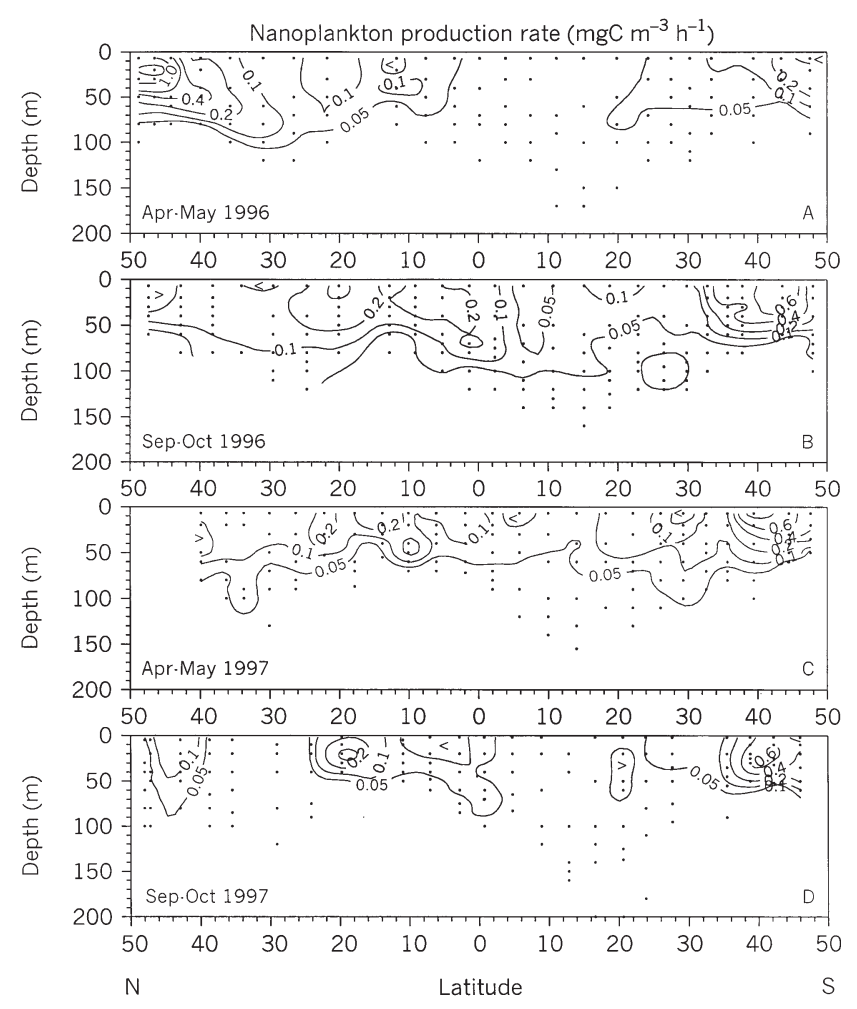

Fig. 7. Latitudinal distribution of primary production in nanoplankton (2 to $20 \mu \mathrm{m})$ size fraction
$0.1 \mathrm{mgC} \mathrm{m}^{-3} \mathrm{~h}^{-1}$ were frequently measured throughout the water column (Fig. 6A,D), although a high degree of inter-cruise variability was observed (see below).

Nanoplankton productivity rates showed a large variability, with values that ranged between $<0.05 \mathrm{mgC}$ $\mathrm{m}^{-3} \mathrm{~h}^{-1}$ at the central gyres and $>0.6 \mathrm{mgC} \mathrm{m}^{-3} \mathrm{~h}^{-1}$ in southern temperate waters, and they reached $>1 \mathrm{mgC}$ $\mathrm{m}^{-3} \mathrm{~h}^{-1}$ in the North Atlantic in May 1996 (Fig. 7). Marked differences between cruises were observed in nanoplankton production at low latitudes; for instance, while values well below $0.05 \mathrm{mgC} \mathrm{m}^{-3} \mathrm{~h}^{-1}$ were measured between 0 and $20^{\circ} \mathrm{S}$ during April 1996, the same area showed productivity rates above $0.1 \mathrm{mgC} \mathrm{m}^{-3} \mathrm{~h}^{-1}$ in October 1996 (Fig. 7A,B). Similar observations of inter-cruise variability were made in the North Atlantic oligotrophic gyre.

Primary production by cells larger than $20 \mu \mathrm{m}$ in diameter represented in most cases the lowest contribution to total production, with values well below $0.05 \mathrm{mgC} \mathrm{m}^{-3} \mathrm{~h}^{-1}$ being measured in vast expanses of the ocean (Fig. 8). In all cruises, the North Atlantic central gyre showed higher microplankton productivity than the South Atlantic central gyre. Relatively high rates ( $>0.2 \mathrm{mgC} \mathrm{m}^{-3} \mathrm{~h}^{-1}$ ) of production in this size fraction occurred only in upwelling and temperate regions.

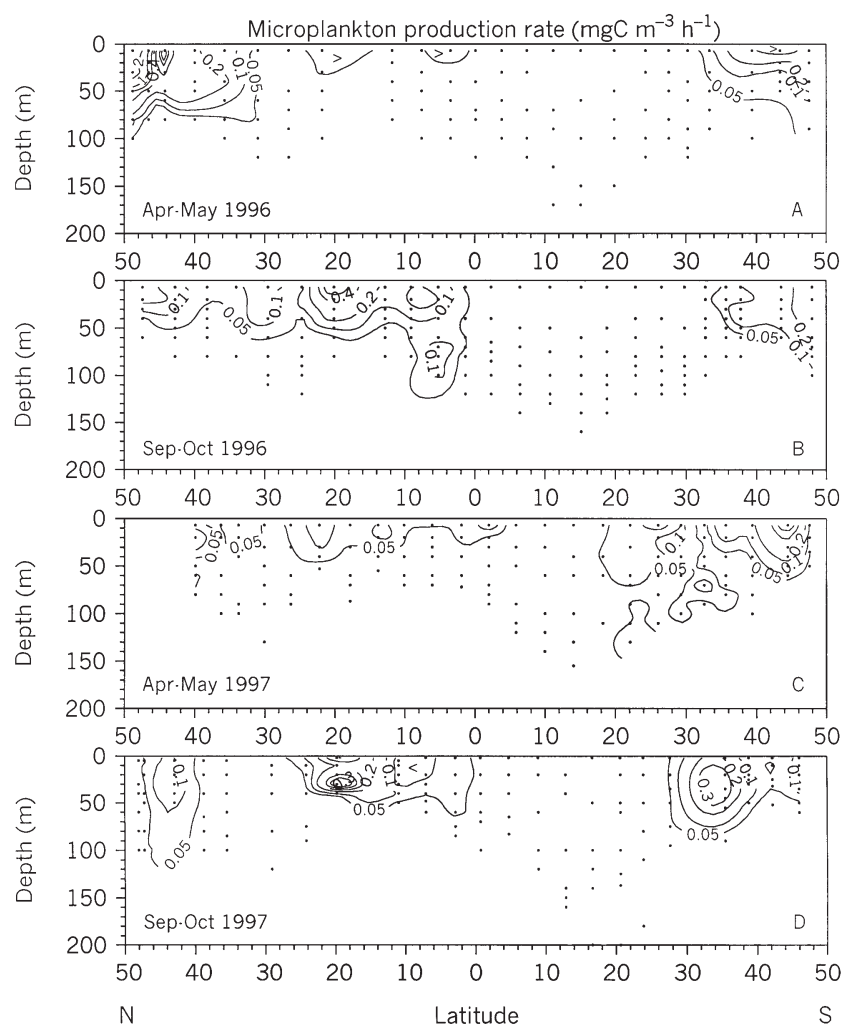

Fig. 8. Latitudinal distribution of primary production in microplankton $(>20 \mu \mathrm{m})$ size fraction 
The highest values of microplankton productivity ( $>2 \mathrm{mgC} \mathrm{m}^{-3} \mathrm{~h}^{-1}$ ) were measured in the North Atlantic during the 1996 spring bloom (Fig. 8A).

In order to better appreciate the extent of the temporal variability in size-fractionated and total productivity during the study, together with the latitudinal changes in the contribution by each size fraction to total C fixation, it is useful to consider the euphotic zone-integrated values shown in Fig. 9. The changes in integrated productivity with latitude were similar on each cruise: higher integrated values ( $>40$ to $60 \mathrm{mgC} \mathrm{m}^{-2} \mathrm{~h}^{-1}$ ) were always recorded in temperate and upwelling waters, whereas the oligotrophic gyres had rates of primary production around $20 \mathrm{mgC} \mathrm{m}^{-2} \mathrm{~h}^{-1}$ or even lower. A substantial amount of variability in the integrated productivity rates was observed in the low-latitude regions, particularly in the South Atlantic. In the region between the equator and $15^{\circ} \mathrm{S}$, productivity rates changed from $<5$ to $10 \mathrm{mgC}$ $\mathrm{m}^{-2} \mathrm{~h}^{-1}$ in May 1996 (Fig. 9A) to $>20$ to $25 \mathrm{mgC} \mathrm{m}^{-2} \mathrm{~h}^{-1}$ in October 1996 (Fig. 9B), again with very low values in October 1997 (Fig. 9D).

The distribution of size-fractionated integrated productivity was characterized by the dominance of picoplankton, which contributed to more than $60 \%$ during most of the transect (Fig. 9). The relative contribution of picoplankton to total primary production decreased markedly in those regions where total productivity increased above 50 to $60 \mathrm{mgC} \mathrm{m}^{-2} \mathrm{~h}^{-1}$, as was the case in the North Atlantic in May 1996 (Fig. 9A) and the South Atlantic in October 1996 (Fig. 9B). Although to a smaller degree, the percentage of total integrated production accounted for by picoplankton also decreased in the low-latitude regions of the South Atlantic. Nanoplankton production usually represented between 20 and $30 \%$ of total $\mathrm{C}$ fixation, while the contribution of microplankton rarely exceeded $20 \%$. In the lowproductivity regions, both nanoplankton and microplankton accounted for a proportion of production that was significantly higher than their share of chl $a$. This was particularly true for the microplankton, which contributed to less than $4 \%$ of total chl a in tropical and subtropical latitudes (Fig. 5) and yet accounted for more than 10 to $12 \%$ of total productivity (Fig. 9). In contrast, the relative contribution of picoplankton to total production was, particularly in the oligotrophic regions, markedly lower than their contribution to total $\mathrm{chl} a$ (Figs. 5 \& 9). We conducted a stepwise linear regression analysis using total integrated production as dependent variable and pico-, nano- and microplankton production as independent variables. Stations with total productivity rates above $60 \mathrm{mgC} \mathrm{m}^{-2} \mathrm{~h}^{-1}$ (less than $13 \%$ of the total number of stations) were excluded from the analysis. Pico-, nano- and microplankton production explained, respectively, 73,7 and $20 \%$ of the variability in total integrated production.

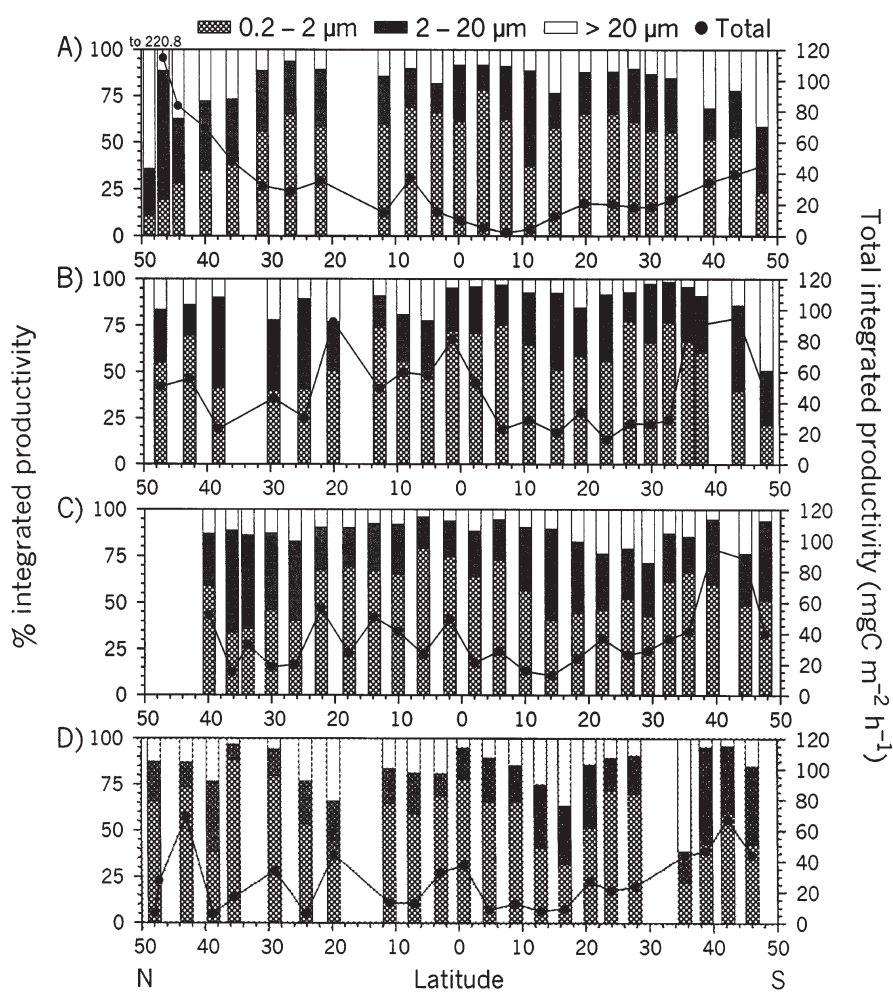

Fig. 9. Total, euphotic layer-integrated primary production $\left(\bullet, \mathrm{mgC} \mathrm{m}^{-2} \mathrm{~h}^{-1}\right)$ and the relative contribution $(\%)$ of picoplankton $(0.2$ to $2 \mu \mathrm{m})$, nanoplankton $(2$ to $20 \mu \mathrm{m})$ and microplankton $(>20 \mu \mathrm{m})$ to total integrated production during (A) April and May 1996, (B) September and October 1996, (C) April and May 1997 and (D) September and October 1997

\section{Characterization of ecological domains}

Taking into account the vertical structure of the water column and the distribution of nutrient and chl a concentrations, we partitioned the sampling transect into 4 ecological domains: temperate, oligotrophic, equatorial and upwelling. The stations sampled at higher latitudes corresponded to the temperate ecological domain, in which the thermocline was weaker or absent, nitrate was detectable throughout the water column and surface chl a concentration was always higher than $0.2 \mathrm{mg} \mathrm{m}^{-3}$. In the AMT cruises, these regions extended from 35 to $50^{\circ} \mathrm{N}$ and from 32 to $50^{\circ} \mathrm{S}$. The oligotrophic regions were defined as those showing a well-developed thermocline, located at a depth greater than $50 \mathrm{~m}$, and an upper mixed layer where nitrate was undetectable (i.e., below $0.05 \mu \mathrm{M}$ ) and $\mathrm{chl}$ a concentration lower than $0.2 \mathrm{mg} \mathrm{m}^{-3}$. The latitudinal range of the oligotrophic regions along the transect was 20 to $35^{\circ} \mathrm{N}$ in the Northern Hemisphere and 5 to $32^{\circ} \mathrm{S}$ in the Southern Hemisphere. The equatorial region, between $5^{\circ} \mathrm{N}$ and $5^{\circ} \mathrm{S}$, was characterized by an 
uplifted thermocline and a shallower deep chl a maximum than the subtropical central gyres (Marañón et al. 2000). Finally, in the upwelling region between 5 and $20^{\circ} \mathrm{N}$, the upper mixed layer extended only for 30 to $40 \mathrm{~m}$, and the chl a maximum was located in subsurface waters at ca $50 \mathrm{~m}$ depth, where nitrate concentrations were higher than $1 \mu \mathrm{M}$.

Following the approach proposed by Tremblay \& Legendre (1994), we calculated the relative contribution of phytoplankton larger than $2 \mu \mathrm{m}$ to total $\mathrm{chl} a$ biomass and production at each station, and then constructed the production-biomass (P-B) diagrams shown in Fig. 10 for each ecological domain. We used the vertically (euphotic layer) integrated results rather than the individual data points from each sampling depth. It can be seen from Fig. 10 that most of the 94 data points fall in the region above the main diagonal, which implies that only occasionally was the contribution by large phytoplankton to total biomass higher than their share of the total productivity.

The temperate domain is the only one which shows several data points in the upper right-hand region of the diagram, corresponding to stations where the large phytoplankton markedly dominated both biomass and production (Fig. 10A). In most of the stations, however, phytoplankton larger than $2 \mu \mathrm{m}$ accounted for 20 to $50 \%$ of the biomass, their contribution to total produc-
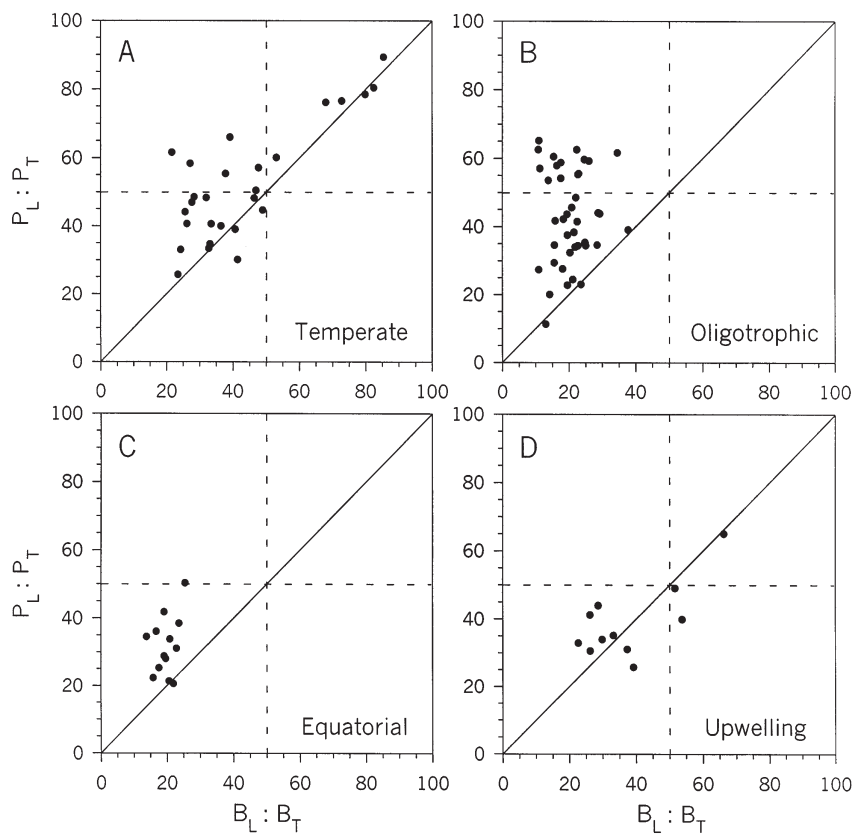

Fig. 10. Production-biomass (P-B) diagrams showing relative contribution (\%) of phytoplankton $>2 \mu \mathrm{m}$ to total integrated biomass $\left(\mathrm{B}_{\mathrm{L}}: \mathrm{B}_{\mathrm{T}}\right)$ and production $\left(\mathrm{P}_{\mathrm{L}}: \mathrm{P}_{\mathrm{T}}\right)$ at a total of 94 stations distributed in temperate $\left(35-50^{\circ} \mathrm{N}, 32-50^{\circ} \mathrm{S}\right)$, oligotrophic $\left(20-35^{\circ} \mathrm{N}, 5-32^{\circ} \mathrm{S}\right)$, equatorial $\left(5^{\circ} \mathrm{N}-5^{\circ} \mathrm{S}\right)$ and upwelling $\left(5-20^{\circ} \mathrm{N}\right)$ ecological domains tivity being somewhat higher (30 to $60 \%$ ). In contrast, the oligotrophic domain was characterized by the total absence of data points in the upper right-hand portion of the diagram in Fig. 10B, implying that picoplankton was always accounting for more than $50 \%$ of both production and biomass. The most striking feature in Fig. 10B is the strong tendency for a departure from the main diagonal, which means that in most cases in the oligotrophic regions the large phytoplankton accounted for a proportion of total productivity that was significantly higher than their share of the total biomass. While the large phytoplankton contribution to total chl a typically ranged between 10 and $30 \%$, the contribution of this size fraction to total productivity was much more variable, ranging from $<20$ to $>60 \%$. A substantial fraction of the data points from the oligotrophic domain fell in the upper left region of the P-B diagram, indicating that a dominance of picoplankton in terms of biomass frequently co-occurred with a dominance of nano- and microplankton in terms of production.

All the data points from the equatorial zone fell in the lower left region of the P-B diagram, i.e., picoplankton always dominated both biomass and production in this domain (Fig. 10C). As was the case in the oligotrophic domain, most of the observations departed from the main diagonal: large phytoplankton accounted for 15 to $25 \%$ of the total biomass, whereas their contribution to total production was higher, taking values between 20 and $40 \%$. In the upwelling region, the large size fraction accounted for a similar share of both biomass and production, although the actual contribution varied amply between 20 and $60 \%$ (Fig. 10D). In this regard, it is important to bear in mind that the AMT cruise track only crossed the edge of the NW Africa upwelling region (Fig. 1), and therefore our results should not be regarded as representative of the effects of this physical feature on the structure and productivity of the planktonic community.

Table 1 summarizes the characteristics of each ecological domain in terms of total and size-fractionated biomass and productivity, and it also provides the average values for the entire sampling transect $\left(50^{\circ} \mathrm{N}\right.$ to $50^{\circ} \mathrm{S}$ ) over the period 1996 and 1997 . The average chl $a$ concentration showed comparatively small changes between regions, ranging from $24 \mathrm{mg} \mathrm{m}^{-2}$ in the oligotrophic domain to $35 \mathrm{mg} \mathrm{m}^{-2}$ in the temperate domain. In contrast, productivity rates changed more widely, from $24 \mathrm{mgC} \mathrm{m}^{-2} \mathrm{~h}^{-1}$ in the oligotrophic regions to $59 \mathrm{mgC} \mathrm{m}^{-2} \mathrm{~h}^{-1}$ in the temperate domain. When compared to the conditions in the subtropical gyres, it can be seen that the upwelling off NW Africa resulted in enhanced productivity rates (42 vs $24 \mathrm{mgC} \mathrm{m}^{-2} \mathrm{~h}^{-1}$ in oligotrophic waters), although its effect on chl a levels was less dramatic (33 vs $24 \mathrm{mg} \mathrm{m}^{-2}$ ). 
Table 1. Average $( \pm \mathrm{SE})$ integrated $\mathrm{chl} \mathrm{a}\left(\mathrm{mg} \mathrm{m}^{-2}\right)$, integrated primary productivity $\left(\mathrm{mgC} \mathrm{m}^{-2} \mathrm{~h}^{-1}\right)$ and relative contribution $(\%)$ of pico-, nano- and microplankton to total chl $a$ and production in each of the 4 ecological domains considered in this study. Also indicated are the weighted average values for the whole data set comprising 94 stations sampled between $50^{\circ} \mathrm{N}$ and $50^{\circ} \mathrm{S}$ during 1996 and 1997. n: number of stations sampled for each region. Statistical significance of the differences between regions was assessed by using the Kruskal-Wallis (K-W) test and the Games-Howell (G-H) a posteriori test. ${ }^{*} p<0.05$; ${ }^{* *} p<0.01$; ${ }^{* * *} \mathrm{p}<0.001$; T: temperate; O: oligotrophic; E: equatorial; U: upwelling

\begin{tabular}{|c|c|c|c|c|c|c|c|}
\hline \multirow[b]{2}{*}{ Variable } & \multirow[b]{2}{*}{$\begin{array}{c}\text { Temperate } \\
\mathrm{n}=29\end{array}$} & \multicolumn{2}{|c|}{ Ecological domain } & \multirow[b]{2}{*}{$\begin{array}{l}\text { Upwelling } \\
\mathrm{n}=11\end{array}$} & \multirow{2}{*}{$\begin{array}{l}\text { Average for } \\
50^{\circ} \mathrm{N}-50^{\circ} \mathrm{S}\end{array}$} & \multirow[t]{2}{*}{$\mathrm{K}-\mathrm{W}$} & \multirow{2}{*}{$\mathrm{G}-\mathrm{H}$} \\
\hline & & $\begin{array}{c}\text { Oligotrophic } \\
n=41\end{array}$ & $\begin{array}{c}\text { Equatorial } \\
n=13\end{array}$ & & & & \\
\hline Total chl a & $35 \pm 4$ & $24 \pm 1$ & $29 \pm 1$ & $33 \pm 4$ & $29 \pm 1$ & ** & $\mathrm{O}<\mathrm{E}$ \\
\hline Total productivity & $59 \pm 8$ & $24 \pm 2$ & $31 \pm 6$ & $42 \pm 7$ & $38 \pm 3$ & $* * *$ & $\mathrm{~T}>\mathrm{O}=\mathrm{E}$ \\
\hline Pico \% chl a & $57 \pm 3$ & $80 \pm 1$ & $80 \pm 1$ & $62 \pm 4$ & $71 \pm 2$ & $* * *$ & $\mathrm{~T}<\mathrm{O}=\mathrm{E}>\mathrm{U}$ \\
\hline Nano \% chl a & $29 \pm 2$ & $16 \pm 1$ & $16 \pm 1$ & $24 \pm 1$ & $21 \pm 1$ & $* * *$ & $\mathrm{~T}>\mathrm{O}=\mathrm{E}<\mathrm{U}$ \\
\hline Micro \% chl a & $14 \pm 3$ & $4 \pm 0$ & $4 \pm 1$ & $14 \pm 4$ & $8 \pm 1$ & $* * *$ & $\mathrm{~T}>\mathrm{O}=\mathrm{E}$ \\
\hline Pico \% productivity & $47 \pm 3$ & $57 \pm 2$ & $69 \pm 2$ & $61 \pm 3$ & $56 \pm 2$ & $* * *$ & $\mathrm{~T}<\mathrm{O}=\mathrm{U}, \mathrm{T}<\mathrm{E}, \mathrm{O}<\mathrm{E}$ \\
\hline Nano $\%$ productivity & $33 \pm 2$ & $30 \pm 2$ & $21 \pm 2$ & $24 \pm 1$ & $29 \pm 1$ & $* *$ & $\mathrm{~T}>\mathrm{E}=\mathrm{U}, \mathrm{O}>\mathrm{E}$ \\
\hline Micro \% productivity & $21 \pm 3$ & $13 \pm 1$ & $11 \pm 2$ & $15 \pm 2$ & $15 \pm 1$ & $*$ & $\mathrm{~T}>\mathrm{E}$ \\
\hline
\end{tabular}

In terms of biomass, the picoplankton always represented the dominant size class. The average contribution of picoplankton to total chl $\mathrm{a}$ in temperate and upwelling regions ( $60 \%)$ was significantly lower than in the oligotrophic and equatorial domains ( 80\%) (Kruskal-Wallis and Games-Howell tests, $\mathrm{p}<0.001$; Table 1). Nano- and microplankton together dominated the productivity in temperate waters, whereas picoplankton accounted for $>55 \%$ of total production in the other regions. The relative contribution of microplankton to total chl a concentration was significantly higher in the temperate domain than in the oligotrophic and equatorial domains (Kruskal-Wallis and Games-Howell tests, p < 0.001; Table 1). The enhanced productivity of the temperate regions was associated with a lower $(<50 \%)$ picoplankton contribution to total production compared to the values observed in the oligotrophic domain. The low-productivity regions were characterized by a marked disparity between the biomass and the production shares of large phytoplankton: microplankton and, to a lesser degree, nanoplankton showed relative contributions to total production that were 2 to 3 times higher than their contribution to total chl a.

\section{Temporal variability in the oligotrophic gyres}

Fig. 11 shows the temporal variability in the average chl a concentration and pro- ductivity rates of the ultra-oligotrophic waters located between $26-35^{\circ} \mathrm{N}$ and $10-20^{\circ} \mathrm{S}$. These latitudinal ranges correspond to the areas of the central gyres where vertical stratification was more intense (see
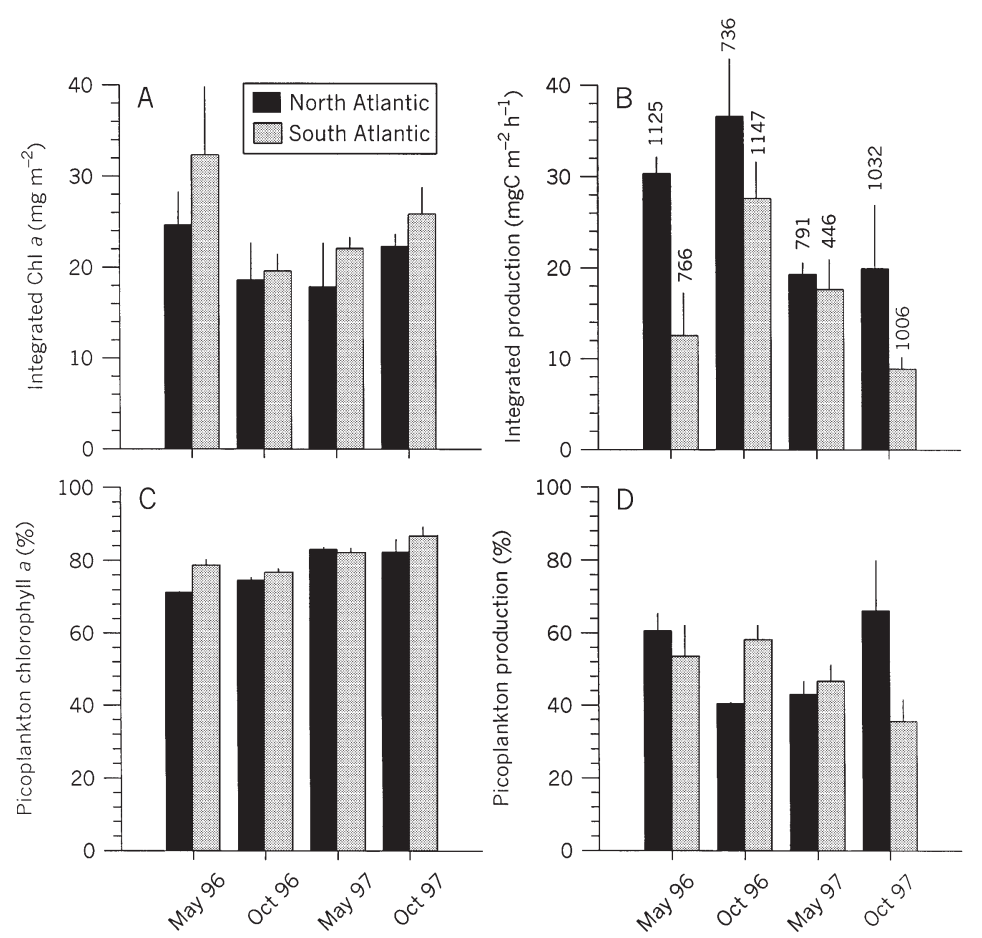

Fig. 11. Temporal variability in ultra-oligotrophic regions of the North (26 to $\left.35^{\circ} \mathrm{N}\right)$ and South $\left(10\right.$ to $\left.20^{\circ} \mathrm{S}\right)$ Atlantic oligotrophic gyres. (A) Total integrated chl a concentration; $(\mathrm{B})$ total integrated primary production; $(\mathrm{C})$ percentage of chl $a$ in the picoplankton $(<2 \mu \mathrm{m})$ size fraction; (D) relative contribution of picoplankton to total integrated production. Error bars represent standard error of the mean. Numbers on top of the error bars in (B) indicate average daily incident irradiance $\left(\mu \mathrm{mol} \mathrm{m}^{-2} \mathrm{~s}^{-1}\right)$ measured at each location on each sampling day 
Fig. 2 in Marañón et al. 2000) and the lowest phytoplankton biomass and production were measured throughout the study period. It can be seen from Fig. 11 that temporal variability in productivity rates was much higher than that of chl a levels. During the 4 cruises, chl a concentration showed relatively small changes, ranging from $\sim 20$ to $\sim 30 \mathrm{mg} \mathrm{m}^{-2}$ (Fig. 11A). In contrast, productivity rates in the oligotrophic gyres changed by a factor of 2 to 3 between May 1996 and October 1997 (Fig. 11B). In North Atlantic oligotrophic waters, productivity changed from $>36 \mathrm{mgC} \mathrm{m}^{-2} \mathrm{~h}^{-1}$ in October 1996 to $<20 \mathrm{mgC} \mathrm{m}^{-2} \mathrm{~h}^{-1}$ in May and October 1997. In the South Atlantic oligotrophic gyre, an integrated production rate of $>27 \mathrm{mgC} \mathrm{m}^{-2} \mathrm{~h}^{-1}$ in October 1996 gave way to a value of $<9 \mathrm{mgC} \mathrm{m}^{-2} \mathrm{~h}^{-1} 1 \mathrm{yr}$ later. These temporal differences in the productivity rates of both oligotrophic gyres proved to be statistically significant (Mann-Whitney test, $\mathrm{p}<0.001$ ). Note that the changes in the productivity rates were not related to differences in incident irradiance (Fig. 11B).

The observed temporal changes in the productivity of the oligotrophic regions were not associated with significant differences in the size structure of the phytoplankton community, as picoplankton contribution to total chl a remained between 77 and $87 \%$ in all the cruises (Fig. 11C). There were some changes in the picoplankton contribution to total production (Fig. 11D), but they were not related to the observed variations in the productivity rates.

\section{DISCUSSION}

\section{Comparison between ${ }^{14} \mathrm{C}$-based and satellite-based productivity estimates}

Our data set of 94 profiles of primary productivity obtained in contrasting seasons along a wide range of open-ocean environments may be used to assess the performance of productivity models based on remotely-sensed chl a fields. In this regard, the model of Longhurst et al. (1995) represents the most comprehensive effort so far to compute marine productivity in the different biogeochemical provinces of the ocean. These authors stress the need to carry out 'further comparisons between modern ${ }^{14} \mathrm{C}$ incubations done at sea and new satellite-based computations'. From their Table 1 we computed the weighted, mean primary production rate for the 5 regions crossed by the AMT transect, and obtained a value of $298 \mathrm{mgC} \mathrm{m}^{-2} \mathrm{~d}^{-1}$, which compares reasonably well with our measured mean rate of $365 \mathrm{mgC} \mathrm{m}^{-2} \mathrm{~d}^{-1}$ (caculated from our Table 1 by assuming a $12 \mathrm{~h}$ photoperiod and $20 \% \mathrm{C}$ loss from dark repiration). Our observations, therefore, support the predictions of this model in what concerns climatological rates of productivity in the Atlantic Ocean between $50^{\circ} \mathrm{N}$ and $50^{\circ} \mathrm{S}$.

\section{Global importance of picophytoplankton}

The dominance of picophytoplankton, both in terms of biomass and production, was a recurrent feature of all the environments sampled during the present study, which included temperate, subtropical, equatorial and upwelling waters. It seems clear that the importance of picophytoplankton cannot be any longer circumscribed to the oligotrophic gyres. Our results suggest that for open-ocean regions with chl a concentrations below $\sim 40 \mathrm{mg} \mathrm{m}^{-2}$ and a rate of primary production below $\sim 60 \mathrm{mgC} \mathrm{m}^{-2} \mathrm{~h}^{-1}$ (equivalent to approximately $570 \mathrm{mgC} \mathrm{m}^{-2} \mathrm{~d}^{-1}$, see below) picophytoplankton are likely to account for around $56 \%$ of the total carbon (C) fixation and near $71 \%$ of the total autotrophic biomass (Table 1).

The observed latitudinal distribution of size-fractionated chl $a$ agreed well with previous knowledge on the phytoplankton species composition along the AMT transect. Picophytoplankton contribution to total chl a was highest in the oligotrophic gyres, where most of the phytoplankton biomass is made up by Prochlorococcus spp. and picoeukaryotic algae (Zubkov et al. 1998). Phytoplankton larger than $2 \mu \mathrm{m}$ in diameter were most important in the upwelling region off Mauritania and in the temperate zones near the ends of the transect (Fig. 5). It is in these regions that the presence of diatoms has been shown to be significant (Marañón et al. 2000). Overall, our size-fractionated chl a data support previous reports indicating that cyanobacteria and small flagellates are the dominant biomass component in the pelagic microbial communities of the Atlantic Ocean (Buck et al. 1996, Zubkov et al. 1998).

In their recent analysis of picoplankton abundance in the ocean, Agawin et al. (2000a) estimated, using data collected from the literature, that picophytoplankton account globally for $39 \%$ of the total primary production but only $24 \%$ of the total biomass (see also Agawin et al. 2000b). Our observations suggest that in open-ocean environments picophytoplankton are quantitatively more important, both in terms of biomass $(71 \%)$ and productivity $(56 \%)$. This discrepancy is probably due to the fact that the analysis by Agawin et al. (2000a) included also coastal estuarine environments, where the relative importance of picophytoplankton is generally smaller than in the open ocean (Tremblay \& Legendre 1994). We now take advantage of our large-scale survey of picophytoplankton chl $a$ and productivity in order to assess the global importance of this group of photoautotrophs. 
The highest average production rate during our study, measured in the temperate domain, was $59 \mathrm{mgC} \mathrm{m}{ }^{-2} \mathrm{~h}^{-1}$ (Table 1). Given that the average photoperiod duration during the AMT study was $12 \mathrm{~h}$ and assuming dark respiratory losses represented $20 \%$ of the light $\mathrm{C}$ incorporation (Geider 1992), this hourly rate translates into a daily rate of ca $570 \mathrm{mgC}$ $\mathrm{m}^{-2} \mathrm{~d}^{-1}$. The regions of the world ocean where the rate of primary production is below $570 \mathrm{mgC} \mathrm{m}^{-2} \mathrm{~d}^{-1}$ extend over $85 \%$ of the total ocean surface and contribute $65 \%$ to the global marine productivity (Longhurst et al. 1995: their Table 1). Our results indicate that picophytoplankton contributed, on average, 56\% of the total primary production between $50^{\circ} \mathrm{N}$ and $50^{\circ} \mathrm{S}$ (Table 1 ). If we consider these data to be representative of the phytoplankton size distribution in those regions of the ocean where the average primary production rate is below $570 \mathrm{mgC} \mathrm{m}^{-2} \mathrm{~d}^{-1}$ (total surface $=27610^{6} \mathrm{~km}^{2}$ ), and assuming that in the remaining areas (total surface $=5210^{6} \mathrm{~km}^{2}$ ) picophytoplankton account for only $10 \%$ of total productivity (Agawin et al. 2000a), then our results imply that picophotoautotrophs are responsible for at least $40 \%$ of the total marine $\mathrm{C}$ fixation, contributing $20 \mathrm{GtC}$ of the total annual estimate of $50.2 \mathrm{GtC}$ calculated by Longhurst et al. (1995).

In order to estimate picophytoplankton biomass, we applied a $\mathrm{C}$ to chl a ratio of 61 (average of all $\mathrm{C}$ to $\mathrm{chl}$ a ratios measured during AMT 1, 2 and 3) to the 94 values of integrated picophytoplankton chl a measured between $50^{\circ} \mathrm{N}$ and $50^{\circ} \mathrm{S}$ and obtained an average picophytoplankton $\mathrm{C}$ biomass of $1.2 \mathrm{gC} \mathrm{m}^{-2}$ for the studied regions. Extrapolating this concentration to the ocean regions with productivity rates below $570 \mathrm{mgC}$ $\mathrm{m}^{-2} \mathrm{~d}^{-1}$, and assuming that in the remaining areas the contribution of picophytoplankton to total phytoplankton biomass is only 10\% (Agawin et al. 2000a), we estimate the global picophytoplankton biomass to be around $0.4 \mathrm{GtC}$, equivalent to $40 \%$ of the total phytoplankton biomass (1 GtC) calculated by Falkowski et al. (1998).

In summary, our observations agree with the results of Agawin et al. (2000a) concerning the global contribution of picophytoplankton to total marine primary production ( $40 \%$ vs $39 \%$ ), but indicate a higher contribution to total phytoplankton biomass (40\% vs $24 \%$ ). The implication is that the average turnover rate of picophytoplankton $\left(0.14 \mathrm{~d}^{-1}\right.$ from the above calculations) does not seem to differ from that of total phytoplankton ( $0.14 \mathrm{~d}^{-1}$ : estimated by Falkowski et al. 1998). It is conceivable that the higher intrinsic growth rates of very small cells (Raven 1998) are counterbalanced by the fact that picophytoplankton are more abundant in the regions of the ocean where nutrient supply is lowest, resulting in slow and nutrient-limited phyto- plankton growth (Falkowski et al. 1992, Graziano et al. 1996, Marañón et al. 2000).

\section{Picophytoplankton variability}

It is often stressed that most of the variability in total phytoplankton biomass is due to changes in the larger size fractions, implying that picophytoplankton abundance remains relatively constant (Raimbault et al. 1988, Rodríguez et al. 1998 among others). This view is undoubtedly true when chl a or biomass distributions spanning several orders of magnitude are considered (e.g. Chisholm 1992, Agawin et al. 2000a). However, it would be misleading to conclude that large-scale latitudinal variations in phytoplankton biomass in the open ocean are mainly due to changes in nano- and microplankton. Over most of the AMT transect, it was picoplankton variability that was driving the changes in total phytoplankton abundance and productivity. For stations with integrated chl a concentrations below $40 \mathrm{mgC} \mathrm{m}^{-2}$ (i.e. $90 \%$ of all the stations visited during this study: see Fig. 5), picophytoplankton chl a explained $61 \%$ of the variability in total chl $a$, whereas nano- and microplankton chl a only explained 29 and 9\%, respectively. In a similar way, picophytoplankton productivity explained $73 \%$ of the variability in total production at the stations where total production was below $60 \mathrm{mgC} \mathrm{m}^{-2} \mathrm{~h}^{-1}$ (i.e. $>87 \%$ of all stations sampled during this study). Our results emphasize the importance of picophytoplankton variability when large spatial scales are considered and suggest that this group of photoautotrophs, rather than simply representing a 'background noise', constitutes an active and changing component of the microbial community in the open ocean, as already stated by Brown et al. (1999).

\section{Characterization of ecological domains}

As explained in the 'Results', the partitioning of the regions sampled within the AMT programme into distinct ecological domains was based on our knowledge of the physical, chemical and biological characteristics of the upper ocean along the cruise track. In this context, the analysis of the relative importance of small and large cells in terms of both biomass and productivity (Fig. 10) is not used to define the boundaries between these domains, but rather to characterize their ecological and biogeochemical functioning. In particular, we are interested in studying the links between plankton community structure, primary productivity and potential $\mathrm{C}$ export. 
The interpretation of size-fractionated chl a data in terms of biomass size structure relies on the assumption that the $\mathrm{C}$ to $\mathrm{chl}$ a ratio does not change across size fractions. Tremblay \& Legendre (1994), working with a data set of 80 measurements of size-fractionated $\mathrm{chl} a$ and phytoplankton $\mathrm{C}$, concluded that no significant differences existed between the $\mathrm{C}$ to $\mathrm{chl}$ a ratio of small and large phytoplankton, irrespective of the size threshold used. Similarly, we have not found any clear pattern of variation in the $\mathrm{C}$ to $\mathrm{chl}$ a ratio along the latitudinal range covered by the AMT cruises, despite the fact that different communities with contrasting size structures have been investigated. Moreover, we found a strong linear correlation between surface chl $a$ and phytoplankton C concentrations (Marañón et al. 2000: see their Fig. 8), which again suggests that changes in cell size were not affecting the $\mathrm{C}$ to chl a ratio in a significant way. Therefore, it is safe to assume that the chl a distribution in different size classes accurately reflects the biomass size structure of the phytoplankton assemblages sampled during the AMT cruises.

In the temperate ecological domain, the relative importance of small and large phytoplankton in terms of both biomass and production showed a high degree of variability (Fig. 10A). This probably reflects the fact that seasonal forcing is particularly relevant at higher latitudes. The occasions on which large phytoplankton accounted for most of the total biomass and production (upper right section of Fig. 10A) corresponded to productive stations sampled near the ends of the transect during spring (Fig. 9). It is well known that the spring bloom in temperate waters is characterized by a dominance of large phytoplankton (mostly diatoms), which account for the majority of the total autotrophic biomass and C fixation (Malone 1980, Hulburt 1990, Joint et al. 1992). Most of the data points in Fig. 10A fall near the main diagonal, which means that the 2 size classes tended to account for a proportion of the total biomass similar to their shares of productivity. This observation implies that in temperate regions a dynamic balance exists between production and loss from grazing and export both for small and large cells. Similar results were obtained by Tremblay \& Legendre (1994) in their analysis of the literature for temperate regions, which included mainly observations from the North Atlantic. The same dynamic balance between production and potential export of small and large cells can be predicted for the upwelling region off Mauritania on the basis of the results shown in Fig. 10D.

The marked dominance of picophytoplankton, particularly in terms of biomass, constituted the most distinctive feature of the phytoplankton size structure in the oligotrophic domain (Fig. 10B). Numerous reports have shown that picophytoplankton dominate the autotrophic biomass in the oligotrophic regions of the north (Platt et al. 1983, Jochem \& Zeitzschel 1993, Malone et al. 1993) and equatorial (Herbland et al. 1985) Atlantic Ocean, although to our knowledge this is the first account of the relative importance of picophytoplankton in subtropical waters of the western south Atlantic. The increased contribution of very small cells to total biomass and productivity in nutrient-poor environments is related to their physiological advantages over larger cells, mainly in terms of nutrient acquisition and use (Raven 1998).

In the oligotrophic regions, we found larger phytoplankton to account for a fraction of the total production that was significantly higher than their share of biomass (points above the main diagonal in Fig. 10B). Other authors have found similar results in a variety of environments, including polar (Legendre et al. 1993), temperate (Tamigneaux et al. 1999) and subtropical (Malone et al. 1993) waters. The occurrence of higher assimilation numbers in nano- and microplankton than in picophytoplankton indicates that size-dependent effects on the light-harvesting processes are not always sufficient to explain the relationship between photosynthetic efficiency and cell size in natural assemblages. Although we do not have enough data to reach a definite conclusion, our results could be explained if, during the productivity experiments, some loss term such as increased cell volume-specific leakage of materials (Raven 1998), or enhanced cells loss due to efficient grazing by microzooplankton (Kiørboe 1993) is higher for picoplankton than for larger cells. From a biogeochemical point of view, the position of the oligotrophic stations in the P-B diagram (Fig. 10B) implies that preferential loss of larger $(>2 \mu \mathrm{m})$ cells takes place in low-production environments, i.e., the export of large cells (through grazing, sedimentation or advection) is higher than their share of production there (Tremblay \& Legendre 1994).

Another distinct characteristic of the oligotrophic domain is that the chl a concentration tended to remain within a relatively narrow range (15 to $30 \mathrm{mg} \mathrm{m}^{-2}$ ) despite wide differences in total productivity (range 2 to $60 \mathrm{mgC} \mathrm{m}^{-2} \mathrm{~h}^{-1}$ ). Given that in the oligotrophic regions physical loss of particles due to advection and vertical mixing are expected to be unimportant, it has been suggested that grazing must play an important role in keeping phytoplankton biomass at low, relatively constant levels (Banse 1995). Recent measurements of intense microzooplankton grazing activity in the subtropical Atlantic Ocean confirm this view (Lessard \& Murrell 1998). As a result, the relationship between the size of the phytoplankton stocks and the rate of primary productivity weakens considerably in these low-production environments (see below).

In the equatorial region between $5^{\circ} \mathrm{N}$ and $5^{\circ} \mathrm{S}$, we encountered higher levels of phytoplankton biomass 
and productivity than in the oligotrophic gyres (Table 1). The increased biological activity of the region can also be visualized in maps of satellite-based productivity (e.g., Behrenfeld \& Falkowski 1997). Is this enhancement of both biomass and production associated with a change in the size structure of the phytoplankton assemblages? Our results show that, at least for the central Atlantic, the equatorial upwelling causes an increase in phytoplankton abundance and productivity without disrupting the typical size structure found in the less productive regions of the oligotrophic gyres. These observations agree with those of Herbland et al. (1987), who concluded that seasonal upwelling in the eastern equatorial Atlantic does not affect the size distribution of primary producers. From the point of view of the size distribution of productivity, the equatorial domain, like the oligotrophic regions, is characterized by a marked dominance of picophytoplankton. As we shall discuss in the next subsection, these results illustrate how changes in planktonic primary production in the open ocean are frequently uncoupled from community structure.

\section{Relationship between phytoplankton production and community structure}

When using data sets of integrated or volumetric phytoplankton biomass and production that include observations from very diverse environments and span several orders of magnitude, it is possible to obtain highly significant inverse relationships between total biomass and production and the relative contribution of picophytoplankton (Chisholm 1992, Agawin et al. 2000a). Our observations, however, indicate that these relationships are of very limited use when applied to the low-productivity regions of the open ocean. In the oligotrophic domain (chl a concentration between 10 and $35 \mathrm{mg} \mathrm{m}^{-2}$ ), there is simply no relationship between total phytoplankton biomass or productivity and the contribution of picophytoplankton to total phytoplankton biomass or productivity. While total productivity in these regions ranged from 2 to $60 \mathrm{mgC}$ $\mathrm{m}^{-2} \mathrm{~h}^{-1}$, the relative contribution of picophytoplankton to total chl a remained fairly stable at 70 to $90 \%$ (Fig. 5). In a similar way, we did not find any significant relationship between total productivity and the relative contribution of small and large phytoplankton to total primary production (Fig. 11). Moreover, there was no significant relationship between integrated primary production and integrated chl a concentration $\left(\mathrm{r}^{2}<\right.$ $0.003, \mathrm{n}=44$ ). The global importance of this lack of relationship between phytoplankton biomass, community structure and primary productivity cannot be overstated, since it occurs in those regions of the open ocean where the average rate of carbon fixation is $\leq 0.3 \mathrm{gC} \mathrm{m}^{-2} \mathrm{~d}^{-1}$. These regions represent $\sim 50 \%$ of the total ocean surface and contribute $\sim 30 \%$ of the total marine primary production (see Table 1 in Longhurst et al. 1995).

Our results showing a lack of relationship between phytoplankton biomass and production are analogous to those of Hayward \& Venrick (1982) for the central North Pacific and Claustre \& Marty (1995) for the tropical North Atlantic. Given that the changes we observed in primary productivity were not related to changes in phytoplankton biomass (Fig. 11A) or irradiance (Fig. 11B; see also Fig. 8A of Marañón \& Holligan 1999), conventional attempts to study phytoplankton dynamics from space using surface chl a data will fail to detect this variability in the carbon fixation rates. The use of additional pigments as markers for different phytoplankton taxa (e.g. Claustre 1994) will not solve this problem, given that variability in productivity exists in spite of constant community structure. We conclude that in the low-productivity regions of the open ocean a significant amount of variability in phytoplankton-mediated biogeochemical fluxes takes place without accompanying changes in the magnitude of the standing stocks, the size structure of the microalgal assemblages, or the type of dominant food-web within the microbial community.

Acknowledgements. Thanks are given to principal scientists Jim Aiken, Tony Bale and Dave Robins for their help during the work at sea, as well as the captain and crew of RRS 'James Clark Ross' for excellent support and smooth sailing. We are grateful to Karl Banse for his constructive criticisms and thorough revision of the manuscript. Three anonymous reviewers also provided valuable comments. E.M. acknowledges the receipt of a grant from the Secretaría Xeral de Investigación e Desenvolvemento of the Xunta de Galicia (Spain) to visit the Southampton Oceanography Centre (UK). This is AMT contribution No. 51.

\section{LITERATURE CITED}

Agawin NSR, Duarte CM, Agustí S (2000a) Nutrient and temperature control of the contribution of picoplankton to phytoplankton biomass and production. Limnol Oceanogr 45:591-600

Agawin NSR, Duarte CM, Agustí S (2000b) Nutrient and temperature control of the contribution of picoplankton to phytoplankton biomass and production (Errata). Limnol Oceanogr 45:1891

Armstrong RA (1994) Grazing limitation and nutrient limitation in marine ecosystems: steady-state solutions of an ecosystem model with multiple food-chains. Limnol Oceanogr 39:597-608

Banse K (1995) Zooplankton: pivotal role in the control of ocean production. ICES J Mar Sci 52:265-277

Behrenfeld MJ, Falkowski PG (1997) Photosynthetic rates derived from satellite-based chlorophyll concentration. Limnol Oceanogr 42:1-20 
Bienfang PK (1984) Size structure and sedimentation of biogenic microparticulates in a subarctic ecoystem. J Plankton Res 6:983-994

Brown SL, Landry MR, Barber RT, Campbell L, Garrison DL, Gowing MM (1999) Picophytoplankton dynamics and production in the Arabian Sea during the 1995 Southwest Monsoon. Deep-Sea Res Part II Top Stud Oceanogr 46: 1745-1768

Buck KR, Chavez FP, Campbell L (1996) Basin-wide distributions of living carbon components and the inverted trophic pyramid of the central gyre of the North Atlantic Ocean, summer 1993. Mar Ecol Prog Ser 10:283-298

Chisholm SW (1992) Phytoplankton size. In: Falkowski PG, Woodhead AD (eds) Primary productivity and biogeochemical cycles in the sea. Plenum Press, New York, p 213-217

Claustre H (1994) The trophic status of various oceanic provinces as revealed by phytoplankton pigment signatures. Limnol Oceanogr 39:1206-1210

Claustre H, Marty JC (1995) Specific phytoplankton biomasses and their relation to primary production in the tropical North Atlantic. Deep-Sea Res 42:1475-1493

Falkowski PG, Barber RT, Smetacek V (1998) Biogeochemical controls and feedbacks on ocean primary production. Science 281:200-206

Falkowski PG, Greene RM, Geider RJ (1992) Physiological limitations on phytoplankton productivity in the ocean. Oceanography 5:84-91

Fasham MJR, Boyd PW, Savidge G (1999) Modeling the relative contributions of autotrophs and heterotrophs to carbon flow at a Lagrangian JGOFS station in the Northeast Atlantic: the importance of DOC. Limnol Oceanogr 44:80-94

Furnas MJ (1983) Community structure, biomass and productivity of size-fractionated summer phytoplankton populations in lower Narrangansett Bay, Rhode Island. J Plankton Res 6:67-90

Geider RJ (1992) Respiration: taxation without representation? In: Falkowski PG, Woodhead AD (eds) Primary productivity and biogeochemical cycles in the sea. Plenum Press, New York, p 333-360

Graziano LM, Geider RJ, Li WKW, Olaizola M (1996) Nitrogen limitation of North Atlantic phytoplankton: analysis of physiological condition in nutrient enrichment experiments. Aquat Microb Ecol 11:53-64

Hayward TL, Venrick EL (1982) Relation between surface chlorophyll, integrated chlorophyll and integrated production. Mar Biol 69:247-252

Herbland A, Le Bouteiller A, Raimbault P (1985) Size structure of phytoplankton biomass in the equatorial Atlantic Ocean. Deep-Sea Res 32:819-836

Herbland A, Le Bouteiller A, Raimbault P (1987) Does the nutrient enrichment of the equatorial upwelling influence the size structure of phytoplankton in the Atlantic Ocean. Oceanol Acta:115-120

Hulburt EM (1990) Description of phytoplankton and nutrients in spring in the western North Atlantic Ocean. J Plankton Res 12:1-28

Jochem FJ, Zeitzschel B (1993) Productivity regime and phytoplankton size structure in the tropical and subtropical North Atlantic in spring 1989. Deep-Sea Res 40:495-519

Jochem G (1989) Distribution and importance of autotrophic ultraplankton in a boreal inshore area (Kiel Bight, western Baltic). Mar Ecol Prog Ser 53:153-168

Joint I, Pomroy A, Savidge G, Boyd P (1992) Size-fractionated primary productivity in the northeast Atlantic in May-July 1989. Deep-Sea Res Part II Top Stud Oceanogr 40:423-440
Karl DM, Christian JR, Dore JE, Hebel DV, Letelier RM, Tupas LM, Winn CW (1996) Seasonal and interannual variability in primary production and particulate flux at Station ALOHA. Deep-Sea Res 43:539-568

Kiørboe T (1993) Turbulence, phytoplankton cell size and the structure of pelagic food-webs. Adv Mar Biol 29:1-72

Legendre L, Gosselin M, Hirche HJ, Kattner G, Rosenberg G (1993) Environmental control and potential fate of sizefractionated phytoplankton in the Greenland Sea $\left(75^{\circ} \mathrm{N}\right)$. Mar Ecol Prog Ser 98:297-313

Legendre L, Le Fèvre J (1991) From individual plankton cells to pelagic marine ecosystems and to global biogeochemical cycles. In: Demers S (ed) Particle analysis in oceanography. Springer-Verlag, Heidelberg, p 261-300

Legendre L, Rassoulzadegan F (1996) Food-web mediated export of biogenic carbon in oceans. Mar Ecol Prog Ser 145:179-193

Lessard EJ, Murrell MC (1998) Microzooplankton herbivory and phytoplankton growth in the northwestern Sargasso Sea. Aquat Microb Ecol 16:173-188

Longhurst A, Sathyendranath S, Platt T, Caverhill C (1995) An estimate of global primary production in the ocean from satellite radiometer data. J Plankton Res 17:1245-1271

Malone TC (1980) Size-fractionated primary productivity of marine phytoplankton. In: Falkowski PG (ed) Primary productivity in the sea. Plenum Press, New York, p 301-319

Malone TC, Pike SE, Conley DJ (1993) Transient variations in phytoplankton productivity at the JGOFS Bermuda time series station. Deep-Sea Res Part I Oceanogr Res Pap 40: 903-924

Marañón E, Holligan PM (1999) Photosynthetic parameters of phytoplankton from $50^{\circ} \mathrm{N}$ to $50^{\circ} \mathrm{S}$ in the Atlantic Ocean. Mar Ecol Prog Ser 176:191-203

Marañón E, Holligan PM, Varela M, Mouriño B, Bale AJ (2000) Basin-scale variability of phytoplankton biomass, production and growth in the Atlantic Ocean. Deep-Sea Res Part I Oceanogr Res Pap 47:825-857

Platt T, Subba Rao DV, Irwin B (1983) Photosynthesis of picoplankton in the oligotrophic ocean. Nature 301:702-704

Raimbault P, Rodier M, Taupier-Letage I (1988) Size fraction of phytoplankton in the Ligurian Sea and the Algerian Basin (Mediterranean Sea): size distribution versus total concentration. Mar Microb Food-Webs 3:1-7

Raven JA (1998) The twelfth Tansley lecture. Small is beautiful: the picophytoplankton. Funct Ecol 12:503-513

Rodríguez J, Blanco JM, Jiménez-Gómez F, Echevarría F, Gil J, Rodríguez V, Ruiz J, Bautista B, Guerrero F (1998) Patterns in the size structure of the phytoplankton community in the deep fluorescence maximum of the Alboran Sea (southwestern Mediterranean). Deep-Sea Res 45: 1577-1593

Sieburth JM, Smetacek V, Lenz J (1978) Pelagic ecosystem structure: heterotrophic compartments of the plankton and their relationship to plankton size fractions. Limnol Oceanogr 23:1256-1263

Tamigneaux E, Legendre L, Klein B, Mingelbier M (1999) Seasonal dynamics and potential fate of size-fractionated phytoplankton in a temperate nearshore environment (Western Gulf of St Lawrence, Canada). Estuar Coast Shelf Sci 48:253-269

Tremblay JE, Legendre L (1994) A model for the size-fractionated biomass and production of marine phytoplankton. Limnol Oceanogr 39:2004-2014

Zubkov MV, Sleigh MA, Tarran GA, Burkill PH, Leakey RJG (1998) Picoplanktonic community structure on an Atlantic transect from $50^{\circ} \mathrm{N}$ to $50^{\circ} \mathrm{S}$. Deep-Sea Res 45:1339-1355 